\title{
Evaluation of Fungicides for the Control of Rice False Smut (Ustilaginoidea virens)
}

\author{
T H Ansari ${ }^{1 *}$, M T Khatun ${ }^{1}$, M Ahmed ${ }^{1}$, B Nessa ${ }^{1}$, M A I Khan ${ }^{1}$, M A Monsur ${ }^{1}$, \\ S Akhter ${ }^{1}, \mathrm{M} \mathrm{A} \mathrm{Ali}^{1}$ and M U Salam ${ }^{2}$
}

\begin{abstract}
Outbreak of false smut, caused by the fungus Ustilaginoidea virens has been recorded in recent years in the popular rice variety 'BRRI dhan 49 ' from various parts of Bangladesh. Registered and/or recommended fungicides are not yet available for chemically controlling the disease. Consequently, uses of unregistered fungicides are common by the farmers for the management of the disease. The present study was, therefore, undertaken to identify effectiveness of any fungicides to control rice false smut disease. Seven synthetic foliar fungicides were evaluated in the naturally induced diseased plots. Each fungicide was applied as spray twice, at panicle initiation and at early flowering stage. Compared to the control (no fungicide application), the fungicide 'Controller $300 \mathrm{EC}^{\prime}$ reduced the hill infection by $57 \%$, followed by 'Green 300 EC', 'Cuprofix 30 Disperss' and Diazole 300 EC, each of those suppressed the hill infection by 50\%. While Cuprofix 30 Disperss, compared to the control, resulted in the lowest number of infected panicle per hill, it was statistically similar to rest of the fungicides except for Confidence 10 SL. Fungicides and control did not have any significant variation on the number of infected florets per panicle. With respect to per unit (hill infection $\times$ number of infected panicle per hill) disease suppression Controller $300 \mathrm{EC}$ was the best. However, none of the fungicides reached the level of the disease suppression, the essential criterion for registration and/or recommendation of a fungicide under Bangladesh conditions. It is concluded that more multi-location and multi-season experiments will be required to reach a decisive conclusion on foliar chemical options for controlling rice false smut disease under Bangladesh conditions.
\end{abstract}

Kew words: Florets, panicles, disease suppression

\section{INTRODUCTION}

Rice false smut (RFSm), caused by Ustilaginoidea virens (Che.) Tak. (teleomorph Villosiclava virens) (White et al., 2000; Tanaka et al., 2008), is one of the most serious diseases of rice world wide (Ou 1972; Rush et al., 2000; Ahonsi and Adeoti 2002; Atia 2004; Bischoff et al., 2004; Tsuda et al., 2006; Zhou et al., 2008; Brooks et al., 2009; Ladhalakshmi et al., 2012; Nessa et $a l ., 2015 \mathrm{a})$. The disease affects rice grains and induces considerable losses both in yield and quality (Atia, 2004). It generally infects 1-15\% of tillers with at least two to three spore balls per infected panicle (Rush et al., 2000; Nessa et al., 2015b). However, the panicle infection may increase to $60 \%$ or higher in years of severe infection causing considerable empty grains and reduced grain weight ( $\mathrm{Li}$ et al., 1986; Lu et al., 2009; Nessa et al., 2015b).

The infection with $U$. virens is reported to be favoured by high relative humidity $(>90 \%)$ (Yashoda et al., 2000), high rainfall (Sugha et al., 1992), low sunshine hours (Nessa et al., 2015c), temperatures in the range of 25 to $30^{\circ} \mathrm{C}$ (Chen et al., 1994; Yashoda et al., 2000), late sowing or maturing (Nessa et al., 2015c; Sarker et al., 2016) and high soil fertility (Singh and Khan 1989, Ahonsi et al., 2000) as well as high amount of nitrogen (Li et al., 1986). In addition, large-scale expansion of high yielding rice varieties or hybrid rice (Singh et al., 1987; Biswas, 2001), over use of chemical fertilizers and more frequent irrigation (Deng, 1989; Zhou et al., 2004; Lu et al., 
2009) also have been recorded as factors for wide spreading of this disease.

RFSm was once considered as minor among the fungi diseases in Bangladesh (Mian and Shahjahan, 1987). Recently, its status has been elevated to major disease due to frequent and widespread occurrence. The outbreak of this disease has been recorded from various parts of Bangladesh predominantly in the variety BRRI dhan49 during T. Aman season. Due to increasing incidence of RFSm in recent years, farmers in Bangladesh are forced to apply fungicides indiscriminately. This is because there is no registered fungicide for the disease and there is no fungicide recommendation to control the disease. This study was, therefore, carried out to elucidate the performance of foliar fungicides in order to ascertain their effectiveness in controlling rice false smut disease under Bangladesh conditions.

\section{MATERIALS AND METHODS}

\section{Experimental site}

The field experiment was carried out during Transplanted Aman season of 2011 in the experimental farm of the regional station, Rajshahi, of the Bangladesh Rice Research Institute (BRRI). The farm is a High Gangetic River Flood Plain located at $24^{\circ} 30^{\prime} \mathrm{N}$ latitude and $38^{\circ} 20^{\prime} \mathrm{E}$ longitude. The soil is calcareous alkaline type and $\mathrm{pH}$ ranged from 7.0-8.2. The weather is hot and humid during Aman season.

\section{Plant material and fungicide}

The high yielding popular T. Aman rice variety BRRI dhan49 was used as test material. Seven fungicides namely Green 30 EC, Confidence
10 SL, Karisma 28 SC, Cuprofix 30 Disperss, Nativo 75 WG, Dizole 300 EC and Controller 300 EC were evaluated against the RFSm disease (Table 1).

\section{Transplanting and management practices}

Thirty-one-day-old seedlings of BRRI dhan 49 were transplanted in a $20 \times 20 \mathrm{~cm}$ spacing on July 25, 2011. The size of individual plots was $3 \times 3 \mathrm{~m}$. Crop husbandries such as irrigation, fertilizers, weeding were done following standard recommended rice production practices (BRRI 2011).

\section{Treatment and experimental design}

Treatment included the seven fungicides and one control (no fungicide application). They were set in a randomized complete block design and replicated three times. Each chemical was sprayed twice, one at panicle initiation stage and the other at early flowering stage. In the experiment field, the disease infection occurred naturally.

\section{Data collection and analysis}

Data were recorded on percentage of hill infection, number of total tillers per hill, number of healthy and infected panicles per hill, number of infected florets per panicle, number of filled and unfilled grains per panicle and thousand-grain weight (TGW). The average values of three replications were then subjected to analysis of variance. The DMRT was performed for the mean comparison when treatment differences were found significant. The data were analysed using CROPSTAT software.

Table 1. List of fungicides with their trade name, chemical group and dose.

\begin{tabular}{lcc}
\hline Trade name & Chemical group & Dose \\
\hline Green 30 EC & Difeconazole+Tebuconazole & $0.8 \mathrm{ml} / \mathrm{L}$ \\
Confidence 10 SL & Validamycine & $3.0 \mathrm{ml} / \mathrm{L}$ \\
Karisma 28 SC & Azoxystrobin+Cyproconazole & $0.8 \mathrm{ml} / \mathrm{L}$ \\
Cuprofix 30 Disperss & Copper+Mancozeb & $4.5 \mathrm{~g} / \mathrm{L}$ \\
Nativo 75 WG & Tebuconazole+Trifloxystrobin & $0.5 \mathrm{~g} / \mathrm{L}$ \\
Dizole 300 EC & Difeconazole+Propiconazole & $0.5 \mathrm{ml} / \mathrm{L}$ \\
Controller 300 EC & Difeconazole+Propiconazole & $0.5 \mathrm{ml} / \mathrm{L}$ \\
\hline
\end{tabular}




\section{RESULTS}

\section{Percent hill infection}

The infection of RFSm in the experimental field ranged from 20.0 to $46.0 \%$ of the hills, where the incidence was the highest in the control (untreated) plots (Table 2). The fungicide Controller appeared to be the best performer reducing the disease by about $57 \%$ (compared to the control). Fungicides Green 300EC, Cuprofix 30 Disperss and Diazole 300 EC decreased the disease incidence by about $50.0 \%$, whereas Karisma 28 SC suppressed the disease by about $46 \%$. Compared to the others, the performance of Confidence 10 SL (disease reduction by $31 \%$ ) and Nativo 75 WG (disease reduction by $25 \%$ ) was poor.

Table 3 shows the number of tillers as well as number of panicles per hill as per treatment. It also shows that fungicides did not affect the total number of tillers and number of panicles per hill.

Number of infected panicles per hill and number of infected florets per panicle

The number of infected panicles per hill was the highest in the control plot (2.51), where as it was lower in the plots treated with fungicides Cuprofix 30 Disperss (1.44) and Controller 300 EC (1.57) (Fig. 1). It may be reiterated that both the fungicides were also found effective in disease reduction in hill infection (50-57\%). The fungicides Diazole 300 EC and Karisma 28 SC also produced relatively less number of infected panicles per hill viz 1.69 and 1.87 respectively, compared to control (2.51).

The number of infected florets per panicle was statistically similar with all the seven fungicides and the control (Fig. 2).

\section{Number of filled grains and unfilled grains per panicle}

None of the fungicides (including the control) showed significant difference in the number of filled grains per panicle (Table 4). Numerically, the highest number of filled grain was found in Cuprofix (145.0) followed by Nativo 75 WG (137.3) and Confidence 10 SL (136.5). The control plots, where no fungicide was applied, produced the lowest number of filled grains per panicle (127.5). This result indicates that
Table 2. Reduction of false smut incidence (\%) in seven fungicides over control.

\begin{tabular}{lcc}
\hline Fungicide & $\begin{array}{c}\text { Hill infection } \\
(\%)\end{array}$ & $\begin{array}{c}\text { Disease reduction } \\
\text { over control (\%) }\end{array}$ \\
\hline Green 30 EC & 23 & 50 \\
Confidence 10 SL & 32 & 31 \\
Karisma 28 SC & 25 & 46 \\
Cuprofix 30 Disperss & 23 & 50 \\
Nativo 75 WG & 36 & 25 \\
Dizole 300 EC & 23 & 50 \\
Controller 300 EC & 20 & 57 \\
Control (untreated) & 46 & - \\
\hline
\end{tabular}

Number of total tillers per hill and number of panicles per hill.

Table 3. Effect of fungicides on the number of total tillers and panicles per hill.

\begin{tabular}{lcc}
\hline Fungicide & $\begin{array}{c}\text { Total tiller/hill } \\
\text { (no.) }\end{array}$ & $\begin{array}{c}\text { Panicles/hill } \\
\text { (no.) }\end{array}$ \\
\hline Green 30 EC & $14.89 \mathrm{a}$ & $13.32 \mathrm{a}$ \\
Confidence 10 SL & $13.40 \mathrm{a}$ & $12.41 \mathrm{a}$ \\
Karisma 28 SC & $13.66 \mathrm{a}$ & $12.41 \mathrm{a}$ \\
Cuprofix 30 Disperss & $13.76 \mathrm{a}$ & $12.34 \mathrm{a}$ \\
Nativo 75 WG & $14.35 \mathrm{a}$ & $12.68 \mathrm{a}$ \\
Dizole 300 EC & $13.64 \mathrm{a}$ & $12.22 \mathrm{a}$ \\
Controller 300 EC & $14.68 \mathrm{a}$ & $13.30 \mathrm{a}$ \\
Control (Untreated) & $13.31 \mathrm{a}$ & $12.06 \mathrm{a}$ \\
\hline
\end{tabular}

Values with the same letters in a column are not significantly different at $\mathrm{p}=0.05$.

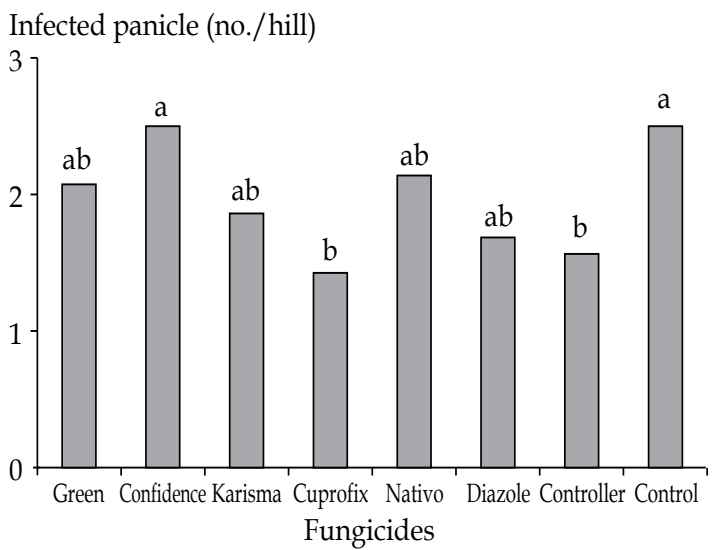

Fig. 1. Number of infected panicles per hill in different fungicides. 


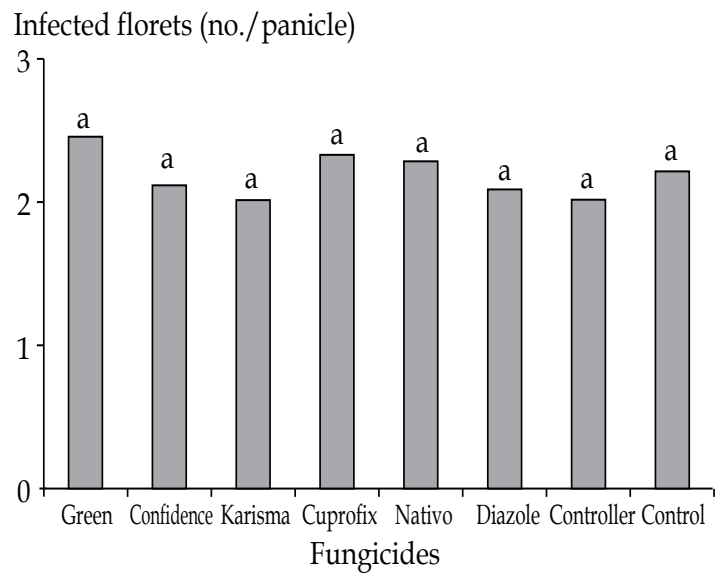

Fig. 2. Number of infected florets per panicle in different fungicides.

fungicides influenced the number of filled grains to a small extent. However, the number of unfilled grains per panicle varied among the fungicide treatments. The lowest unfilled grains was recorded in Confidence $10 \mathrm{SL}$ (14.87) followed by Controller 300 EC (15.80). On the other hand, the highest unfilled grain was recorded in Green 30 EC (29.8) followed by Dizole 300 EC (23.3).

\section{Thousand-grain weight (g)}

There were significant differences among the seven fungicides for the trait TGW (Table 4). Maximum TGW was obtained from the fungicides Cuprofix $(30.6 \mathrm{~g})$ followed by Nativo $(27.0 \mathrm{~g})$ and Karisma $(25.9 \mathrm{~g})$. On the other hand, it was the lowest in the fungicides Diazole (20.7 g) and Confidence (23.4 g). TGW for the control plot was $24.3 \mathrm{~g}$.

\section{DISCUSSION}

The present investigation evaluated the efficacy of seven synthetic foliar fungicides for the control of rice false smut under natural disease incidence scenario. We found that Green 30 Dizole 300 EC and Controller 300 EC had reduced the disease severity (\% hill infection) substantially compared to the untreated plot. Other tested fungicides viz, Confidence 10 SL, Karishma 28 SC and Nativo 75 WG were comparatively less effective. The fungicides Controller 300 EC showed highest efficacy to control this disease. Green 300 EC, Cuprofix 30 Disperss and Dizole 300 EC also recorded as moderately good for their efficiency to overcome this disease. Chen et al., 1994 found that spraying plants with copper oxychloride or thiophanate-methyl at booting stage reduced RFSm. Pramjit et al. (2006) reported that Tilt 25 EC (Propiconazole) and Contaf 5 EC (Hexaconazole) effectively controlled the RFSm incidence when these fungicides were applied at boot stage. Many authors reported that the fungus invade into rice spikelets before heading of rice plants i.e., at the booting stage (Ashizawa and Kataoka 2005; Zhou et al., 2003) and infect rice florets. We sprayed the fungicide started at panicle initiation and further at early flowering stage and hence the above mentioned three difeconazole+propiconazole/ tebuconazole fungicides especially Controller 300 EC might had effectively controlled the invasion of fungi into florets. Controller $300 \mathrm{EC}$ has been prepared from propiconazole mixing with difeconazole. Therefore the result of this

Table 4. Number of filled grain, unfilled grain and 1000-grain weight in different fungicide treatments.

\begin{tabular}{lccc}
\hline Treatment & Filled grain/ panicle (no.) & Unfilled grain/panicle (no.) & $\begin{array}{c}\text { 1000 Grain } \\
\text { weight (g) }\end{array}$ \\
\hline Green 30 EC & $130.3 \mathrm{a}$ & $29.80 \mathrm{a}$ & $24.2 \mathrm{ab}$ \\
Confidence 10 SL & $136.5 \mathrm{a}$ & $14.87 \mathrm{~b}$ & $23.4 \mathrm{ab}$ \\
Karisma 28 SC & $131.9 \mathrm{a}$ & $17.87 \mathrm{ab}$ & $25.9 \mathrm{ab}$ \\
Cuprofix 30 Disperss & $145.0 \mathrm{a}$ & $20.80 \mathrm{ab}$ & $30.6 \mathrm{a}$ \\
Nativo 75 WG & $137.3 \mathrm{a}$ & $15.53 \mathrm{~b}$ & $27.0 \mathrm{ab}$ \\
Dizole 300 EC & $135.9 \mathrm{a}$ & $23.27 \mathrm{ab}$ & $20.7 \mathrm{~b}$ \\
Controller 300 EC & $130.9 \mathrm{a}$ & $15.80 \mathrm{~b}$ & $21.4 \mathrm{ab}$ \\
Control (Untreated) & $127.5 \mathrm{a}$ & $24.33 \mathrm{ab}$ & $24.3 \mathrm{ab}$ \\
\hline
\end{tabular}

Values with the same letters in a column are not significantly different at $\mathrm{p}=0.05$. 
study is partially comply with the previous report (Paramjit et al., 2006).

We noticed that the number of total tillers per hill and number of panicles per hill had no significant differences among the tested chemicals implied that neither the fungicides nor the infection of false smut had any impact for the afore mentioned traits. Although Chlamydospores germinate on coleoptile cells and can invade through intercellular space, but it had no influence on tillering of the plant. Disease infection process of false smut generally happened in the florets at the booting stage, when the effective tiller has already determined. However, there were notable differences for the number of infected panicles per hill. The fungicides Cuprofix 30 Disperss and Controller 300 EC were identified as good for the control of infected panicles per hill. Yashoda et al. (2000) also reported the similar results. They found that Carbendazim reduced the disease severity significantly. The nature of RFSm incidence generally happened sporadically or aggregation in spaces in the rice field (Nessa et. al., 2015b; Rush et al., 2000). The tested fungicides could not prevent the fungi similarly might be due to nature of natural inoculum distribution pattern in the field. Not only the sporadic distribution pattern of false smut inoculum but also the level of inoculum pressure or aggregation might have influence on the prevention capacity of tested fungicides against the disease.

Epidemiological studies revealed that the chlamydospores survive in the soil and become a primary source of infection of the rice plants. Germinated chlamydospores on coleoptile epidermal cells invade intercellularly and reach the meristematic tissues of rice plants (Ikegami 1962). It was also found that the infection levels became very low after the coleoptiles reached 10 $\mathrm{mm}$ in length. However, the fungus invade into rice spikelets before heading i.e., at the booting stage (Ashizawa and Kataoka 2005; Zhou et al., 2003) and infect rice florets. Artificial inoculum pressure by injecting conidia and hyphae at the booting stage induced more floret infection and thereby larger number of smut balls $(\mathrm{Hu}$ et al., 2013). The epidemiology of the disease is relatively well studied, but the relationship between the pathogen population density in the soil, their distribution pattern in the field and disease severity in the paddy fields are unknown. These might have influenced in the difference of panicle infection in association with the varied level of fungicides effect.

TGW also varied considerably among the treated plot. We observed that the fungicides Cuprofix 30 Disperss and Nativo 75 WG increased grain weight more than the control plot, indicated that fungicides might have increased the grain weight of rice. Our findings were also supported by different researchers (Yashoda et al., 2000; Paramjit and Sweety, 2006). They noticed that the application of fungicides not only increased the yield but also improved the quality of rice grain. However, grain weight was comparatively lower in the Controller 300 EC and Dizole 300 EC treated plots but these fungicides controlled the disease better. Therefore, it is necessary to check further whether these fungicides have any negative effect on the grain weight.

\section{CONCLUSION}

In conclusion, the fungicide Controller 300 EC reduced the hill, panicle and rice floret infection more compared to other tested fungicides. Cuprofix 30 Disperss was effective next to the Controller 300 EC. However, none of the fungicides was found effective for the complete control of false smut disease in rice. This findings echo the results from a recently conducted field survey (Sarker et al., 2016). Previous reports (Chen et al., 1994; Paramjit et al., 2006), the results and above discussion indicate that mixture of propiconazole with copper fungicides might be more effective in controlling the false smut disease in rice. Further investigation in this regard is suggested.

\section{ACKNOWLEDGEMENTS}

The research was carried out by the financial support from the ministry of Agriculture, the Peoples Republic of Bangladesh. We thankfully acknowledge supports of the field staffs of BRRI RS, Rajshahi during the implementation of the study. 


\section{REFERENCES}

Ahonsi, M O, A A Adeoti, I D Erinle, T A Alegbejo, B N Singh and A A Sy. 2000. Effect of variety and sowing date on false smut incidence in upland rice in Edo State, Nigeria. IRRI Notes. 25(1): 14.

Ahonsi, M O and A A Adeoti. 2002. False smut on upland rice in eight rice producing locations of Edo State, Nigeria. J. Sustain. Agri. 20(3): 81-94.

Ashizawa, T and Y Kataoka. 2005. Detection of Ustilaginoidea virens in rice panicles before and after heading in the field using nested-PCR technique with species-specific primers. Japanese J. Phytopath. 71(1): 16-19.

Atia, M M M. 2004. Rice false smut (Ustilaginoidea virens) in Egypt. J. Pl. Dis. Prot. 111(1): 71-82.

Bischoff, J F, R F Sullivan, K M Kjer and J F White. 2004. Phylogenetic placement of the anamorphic tribe Ustilaginoideae (Hypocreales, Ascomycota). Mycologia. 96(5): 1088-1094.

Biswas, A. 2001. Field reaction of hybrid rice varieties to false smut (FS) and kernel smut (KS) disease in West Bengal, India. Environm. Ecol. 19: 229-230.

Brooks, S A, M M Anders and K M Yeater. 2009. Effect of cultural management practices on the severity of false smut and kernel smut of rice. Plant Disease. 93(11): 1202-1208.

BRRI (Bangladesh Rice Research Institute). 2011. Adhunik Dhaner Chash (Modern Rice Cultivation). Sixteenth edition. Pp. 72.

Mian, S A and A K M Shahjahan. 1987. Mathe dhaner rog nirnoy o tar protikar (Determination of rice disease in the field and its management). First edition. p. 60.

Chen, Z Y, S Z Yin and Y L Chen. 1994. Biological characteristics of Ustilaginodea virens and the screening in vitro of the causal pathogen of false smut of rice and fungicides. Chinese Rice Research Newsletter (CRRN). 2(1): 4-6.

Deng, GS. 1989. Present Status of Research on False Smut in China," Plant Protection (Chinese). Vol. 15(6): 39-40.

$\mathrm{Hu}, \mathrm{M}$, L Luo, S Wang, Y Liu and J Li. 2015. Infection processes of Ustilaginoidea virens during artificial inoculation of rice panicles. Eur J. Plant. Pathol. 139: 67-77. DOI 10.1007/s10658-013-0364-7.

Ikegami, H. 1962. Study on the false smut of rice. V. Seedling inoculation with the chlamydospores of the false smut fungus. Annals of the Phytopath. Soc. Japan. 27: 16-23.

Ladhalakshmi, D, G S Laha, R Singh, A Karthikeyan, S K Mangrauthia, R M Sundaram. 2012. Isolation and characterization of Ustilaginoidea virens and survey of false smut disease of rice in India. Phytoparasitica. 40(2): 171-176.

Li, Y G, B J Kang, B D Zhang, H Z Zeng, K X Xie, Y T Lan, $\mathrm{H}$ Ma and T F Li. 1986. A preliminary study on rice false smut. Guangdong Agricul. Sci. 4: 45-47.

Lu, D H, X Q Yang, J H Mao, H L Ye, P Wang, Y P Chen, Z Q He and F Chen. 2009. Characterising the pathogenicity diversity of Ustilaginoidea virens in hybrid rice in China, Journal of Plant Pathology. 91(2): 443-451.
Nessa, B, M U Salam, A H M M Haque, J K Biswas, W J MacLeod, M A Ali, K P Halder and J Galloway. 2015a. FLYER: A simple yet robust model for estimating yield loss from rice false smut disease (Ustilaginoidea virens). Am. J. Agril. Biol. Sci. 10: 41-54.

Nessa, B, M U Salam, A H M M Haque, J K Biswas, M S Kabir, W J MacLeod, M D'Antuono, H N Barman, M A Latif and J Galloway. 2015b. Spatial pattern of natural spread of rice false smut (Ustilaginoidea virens) disease in fields. Am. J. Agril. Biol. Sci. 10: 63-73.

Nessa, B, M U Salam, A H M M Haque, J K Biswas, M A Latif, M A Ali, T H Ansari, M Ahmed, N Parvin, M Z I Baki, S Salam, M S Islam and J Galloway. 2015c. Rice false smut disease at different times of flowering. Bangladesh Rice J. 19: 29-35.

Paramjit, S B and K Sweety. 2006. Evaluation of fungicides for controlling false smut (Ustilaginoidea virens) of rice. Indian Phytopath. 59(1): 115-117.

Ou, S H. 1972. Rice Diseases. Commonwealth Mycological Institute, Kew, Surrey, UK. 288-295.

Rush, M C, A K M Shahjahan, J P Jones and D E Groth. 2000. Outbreak of false smut of rice in Louisiana. Plant Disease. 84(1): p. 100. http://dx.doi.org/10.1094/ PDIS.2000.84.1.100D.

Singh, G P, R N Singh, A Singh. 1987. Status of false smut (FS) of rice in eastern Uttar Pradesh, India. IRRINewsletter. 12(2): 28.

Singh, R N and A T Khan. 1989. Field resistance to false smut (FS) and narrow brown leaf spot (NBLS) in eastern Uttar Pradesh. IRRI-Newsletter. 14(4): 16-17.

Sugha, SK, O PSharma, and R P Kaushik. 1992. Performance of rice genotypes against false smut pathogen under rainfed conditions. Pl. Dis. Res. 8: 76-77.

Tanaka, E, T Ashizawa, R Sonoda and C Tanaka. 2008. Villosiclava virens gen. nov., com. nov., teleomorph of Ustilaginoidea virens, the causal agent of rice false smut. Mycotaxon, 106: 491-501.

Tsuda, M, M Sasahara, T Ohara and S Kato. 2006. Optimal application timing of simeconazole granules for control of rice kernel smut and false smut. J. Gen. Plant. Pathology, 72(5): 301-304.

White, J F, R M M Sullivan, R Patel and R Duncan. 2000. An overview of problems in the classification of plantparasitic Clavicipitaceae. Studies in Mycology, 45: 95-105.

Yoshoda, H, K H Anahosur and K Srikant. 2000. Chemical control of false smut of rice caused by Claviceps oryzae- sativae Hashioka. Karnataka J. Agri. Sci. 13(3): 623-627.

Zhou, Y L, J J Fan, C Z Zeng, X Z Liu, S Wang, and K J Zhao. 2003. Preliminary analysis of genetic diversity and population struction of Ustilaginoidea firens. Acta Phytopathology Sinica, 34: 436-445. (in Chinese with English abstract)

Zhou, Y L, Y J Pan, X W Xie, L H Zhu, S Wang and Z $\mathrm{K}$ Li. 2008. Genetic diversity of rice false smut fungus, Ustilaginoidea virens and its pronounced differentiation of populations in north China. J. Phytopath. 156(9): 559-564. 